\title{
Association of Institutes for Bee Research Report of the 54th seminar in Veitshöchheim, 27-29 March 2007
}

The following two abstracts should have been published in the Report of the 54th Seminar of the Association of Institutes for Bee Research (issue No. 5/2007).

28. The nest architecture of Plebeina hildebrandti (Apidae, Meliponini) inhabiting termite mounds in Kawanda, Uganda. F.N. Namu, D. Wittmann (Fb. Ökologie der Kulturlandshaft- Tierökologie, Universität Bonn, 53127 Bonn, Germany)

In Africa meliponiculture is not practised and honey harvesting is destructive. To facilitate stingless bees rearing, we described the nest architecture of Plebeina hildebrandti (Friese) in Uganda. Nine nests were excavated in inhabited termite mounds. The nests were located in the nursery (hive) part of the mounds. The bees modified cavities and tunnels dug by the termites. Entrance tubes protruding above the termite mounds had heights of $0-25 \mathrm{~cm}$ and $1 \mathrm{~cm}$ diameter. The tubes varied in concealment, rigidity, and perforations. Sticky resin droplets around the tubes trapped intruders. Entrance tubes through the termite mound were $44-120 \mathrm{~cm}$ long. Inside the tubes were amorphous and elongate bars of resin that deterred and provided resin to immobilize intruders. The nest cavities had a mean height of $18.8 \mathrm{~cm}$ and $12.4 \mathrm{~cm}$ width, lined with $0.1 \mathrm{~cm}$ resin. In some nests short pillars emerged from the resin lining and connected to the storage pots, while in others a soft involucrum layer separated the resin lining and the storage pots. Groups of pollen pots, average height $1.2 \mathrm{~cm}$; width $0.7 \mathrm{~cm}$, and nectar pots, height $1.2 \mathrm{~cm}$; width $1.3 \mathrm{~cm}$, were separated from brood combs by an involucrum layer. There were 6-10 circular, trapezoidal or both combs in a nest. Comb diameter was $8-16 \mathrm{~cm}$ and separated by pillars with lengths of $0.5-0.8 \mathrm{~cm}$. In a nest, there were $3300-3775$ brood cells with an average height of $0.5 \mathrm{~cm}$ and diameter $0.3 \mathrm{~cm}$. Queen cells had a mean height of $0.8 \mathrm{~cm}$ and diameter of $0.5 \mathrm{~cm}$ located in a central hole in the combs. A slanting drainage tube with a mean length of $38.3 \mathrm{~cm}$ and $1 \mathrm{~cm}$ wide originated from the base of the nest cavity. Nest architecture is a species specific trait which can support identification of species and give information on how a species can be reared for honey production and pollination.

31. Banana Wilt in East Africa: Are stingless bees vectors of Xanthomonas campestris musacearum? F.N. Namu, D. Wittmann ((Fb. Ökologie der Kulturlandshaft- Tierökologie, Universität Bonn, 53127 Bonn, Germany)

Banana Xanthomonas Wilt (BXW) emerged and spread in Uganda in year 2001. By 2006, the disease had spread to neighbouring countries. The first symptoms of infections appeared on the male flowers indicating insect or animal vectors. Due to their social life, stingless bees were speculated to be the main vector. Through field and laboratory observations we investigated which resources stingless bees collected from bananas. We determined the nectar volume and sugar concentration of the most susceptible banana variety Pisang (Kanyija). The findings were: five species Hypotrigona gribodoi (Magretti), Plebeina hildebrandti (Friese), Meliponula ferruginea (Lepeletier) and Meliponula sp. collected nectar from bananas. P. hildebrandti was the most common on the banana flowers. The bees did not collect banana sap and infected ooze. Banana sap introduced inside the nest of $P$. hildebrandti was covered with resin. Pisang had an average of $30.5 \mu \mathrm{L}$ nectar per flower and mean sugar concentration of $14.1 \%$ (2-32\%). Since stingless bees are known to take up nectar with sugar concentration of $45-60 \%$, we determined how far $P$. hildebrandti would fly to collect banana nectar using $11,33,48$, and $54 \%$ sugar solutions. To collect $11 \%$ sugar solution bees flew up to $1050 \mathrm{~m}$, for $33 \%$ solution $1200 \mathrm{~m}$, for $48 \%$ solution $1220 \mathrm{~m}$ and for $54 \%$ solution $1230 \mathrm{~m}$. Therefore, for Pisang nectar, bees are likely to fly up to $1200 \mathrm{~m}$. Consequently if Xanthomonas is in nectar, stingless bees can spread it, for only short distances. Potential long distance vectors such as honey bees, birds, bats and humans require investigations. 